\title{
PEMBELAJARAN MATEMATIKA BERBASIS STEM: IMPLEMENTASI VARIASI PENGEMBANGAN MODEL PEMBELAJARAN STEM DI SEKOLAH DASAR
}

\author{
Hardani \\ UPTD SDN Tambegan Bangkalan, hardanisaja@gmail.com
}

\begin{abstract}
Abstrak. STEM merupakan pendekatan pembelajaran yang mengintegrasikan sains, teknologi, teknik dan matematika dalam kegiatan berbasis pemecahan masalah. Integrasi keempat disiplin keilmuan dalam kegiatan proyek STEM menggunakan tahapan Engineering Design Process (EDP). Tahapan ini merupakan siklus dalam bentuk langkah-langkah berulang dan dapat berganti hingga solusi pemecahan masalah teridentifikasi. Karakteristik dan tahap perkembangan kognitif peserta didik di sekolah dasar yang berbeda serta tidak adanya kurikulum STEM tersendiri, mengakibatkan guru yang baru mengenal STEM mengalami kesulitan untuk mengimplementasikan model yang ada. Oleh karena ini perlu pengembangan tahapan model pembelajaran STEM yang sesuai dengan karakteristik guru dan siswa. Tahapan ini dikembangkan dengan tujuan agar STEM menjadi lebih mudah diterapkan dan mudah mengkoneksikan permasalahan dengan pengembangan produk hasil proyek STEM. Variasi model pembelajaran STEM yang dikembangkan ini meliputi tahapan: create, identify, ideat, plan, build, communicate. Desain Model Pembelajaran STEM yang dikembangkan ini akan mempermudah guru dalam mengimplementasikan STEM dalam pembelajaran di kelas.
\end{abstract}

Kata Kunci. Pembelajaran Matematika, Pengembangan Model STEM

\section{STEM Based Mathematics Learning: Variation Implementation of The STEM Learning Model Development In Elementary School}

\begin{abstract}
STEM is a learning approach that integrates science, technology, engineering and mathematics in the problem-solving based activities. The integration of the four scientific disciplines in STEM project activities uses the Engineering Design Process (EDP) stage. This stage is a cycle in the form of repeated steps and might change until a problem-solving solution is identified. The difference of elementary school students' characteristics and stages of cognitive development as well as the absences of a specific STEM curriculum causes teachers who are new to STEM find it difficult in implementing the existing model. Therefore, it is necessary to develop the stages of the STEM learning model in accordance with the characteristics of teachers and students. This stage was developed with the aim of making STEM easier to apply and easily connecting problems with product development from the STEM project. The variation of the STEM learning model developed includes the stages: create, identify, ideate, plan, build, and communicate. The STEM Learning Model design developed will make it easier for teachers to implement STEM in classroom learning.
\end{abstract}

Keyword. Mathematics Learning, STEM Model Development 


\section{Pendahuluan}

Perubahan paradigma belajar bergeser pada upaya peningkatan keterampilan yang harus dimiliki oleh peserta didik sebagai wujud upaya penyiapan sumber daya manusia melalui pembelajaran. Pembelajaran di abad ke-21 menuntut menuntut keterampilan berpikir kritis, kreatif, inovatif dan kolaborasi. Keterampilan ini sangat dibutuhkan untuk memecahkan berbagai masalah dalam kehidupan yang semakin kompleks. Matematika sebagai salah satu pembelajaran yang dekat dengan kehidupan. Matematika mempunyai peran yang sangat penting dan menjadi dasar perkembangan ilmu yang lain (Yusnita, Masykur\& Suherman, 2016). Namun demikian kenyataannya penguasaan materi, keterampilan teknik dan berhitung, belum mengembangkan keterampilan yang menjadi esensi dari belajar matematika itu sendiri (Sumaryanta \& Agus, 2020).

STEM merupakan salah satu pendekatan pembelajaran yang dapat digunakan dalam pembelajaran matematika yang sesuai dengan kurikulum 2013 (Gustiani, Widodo \& Suwarma, 2017). Salah satu keberhasilan pembelajaran STEM ditentukan pada rekayasa (engineering) sebagai kekuatan yang mendukung pemecahan masalah. Engineering merupakan siklus atau tahapan yang menjadi salah satu ciri kegiatan pembelajaran STEM. Engineering tersebut memadukan beberapa proses yaitu pemecahan masalah, desain, pembuatan dan revisi produk (English, 2016). Permasalahan sebagai titik tolak dalam pembelajaran berbasis STEM, dibangun dan dihubungkan melalui Engineering Design process (EDP). Jolly (2016) menyatakan bahwa EDP dalam STEM merupakan suatu cara sistematis, teratur dan terbuka untuk mendekati masalah dan merancang solusi untuk permasalahan tersebut. Dalam proses EDP, permasalahan yang diberikan pada peserta didik pada proses pembelajaran. Hal ini didasarkan pada tujuan STEM merupakan bentuk inovasi untuk menyelesaikan masalah pada dunia nyata.

Proses EDP dalam STEM dapat mengembangkan keterampilan berpikir kritis dan kreatif melalui hasil karya. Produk karya inovasi ini merupakan solusi dari peserta didik sebagai upaya meningkatkan kemampuan mereka memecahkan masalah dunia nyata yang komplek. Melalui EDP ini pula peserta didik akan mengetahui dan memahami bahwa banyak ide atau cara untuk solusi pemecahan masalah yang komplek. (English \& King, 2015). Solusi yang diperoleh sesuai dengan hasil akhir dari suatu proses kegiatan ini merupakan sebuah karya peserta didik sesuai dengan tingkat dan perkembangan berpikir pada usia mereka.

STEM sebagai pendekatan yang dianggap baru bagi sebagian guru sekolah dasar membuat mereka sulit untuk mengimplementasikanya di kelas-kelas. Kesulitan bagi guru diantaranya; (1) menentukan permasalahan dan produk hasil STEM; (2) integrasi keempat disiplin keilmuan STEM dalam proyek. Permasalahan tersebut salah satunya disebabkan belum adanya kurilum khusus STEM di sekolah dasar, integrasi muatan materi masih didasarkan pada kompetensi dasar yang ada di kurikulum nasional. STEM sebagai suatu kegiatan bukan hal yang baru dikenalkan pada siswa usia sekolah dasar baik formal maupun informal. Kegiatan STEM seperti membuat parasut dari plastik, kincir angin dari kertas, mobilmobilkan dari kulit jeruk, kapal dan pesawat dari kertas serta masih banyak lagi.

Dalam praktik STEM khususnya di sekolah dasar didasarkan pada tahap perkembangan kognitif siswa. Hasil karya STEM tidak harus berupa produk yang berdampak nyata dalam 
kehidupan, tetapi dapat berupa prototype. Berbagai kegiatan STEM yang dilakukan pakar STEM di camp mereka lebih pada kegiatan joyful learning. Kegiatan ini mengandung makna kegiatan yang menyenangkan tetapi mempunyai kebermaknaan tinggi untuk mengembangkan keterampian berpikir kritis, kreatif, kolaborasi dan komunikasi dalam proses EDP dengan mengintegrasikan unsur STEM.

Permasalahan merupakan kegiatan awal dalam proses EDP yang dapat disajikan melalui media gambar, video atau teks cerita. Berdasarkan pada kegiatan praktik STEM yang telah dilakukan oleh penulis, media sebagai stimulus tersebut kurang begitu efektif digunakan jika produk fisik merupakan hasil dari kegiatan proyek. Perlu adanya kegiatan atau produk yang lebih konkrit untuk dijadikan sebuah permasalahan yang dapat dikembangkan lebih lanjut. Hal ini juga didasarkan pada tahap perkembangan peserta didik di usia sekolah dasar. Proses pembelajaran di SD berpedoman pada aspek kognitif sebagai pedoman kegiatan belajar hingga penilaian (Riyatul Jannah, 2020). Konteks perkembangan kognitif peserta didik yang berorientasi pada tahap operasional konkrit. Oleh karena itu proses adaptasi STEM dalam pembelajaran membutuhkan model pembelajaran STEM yang fleksibel. Sehingga perlu adanya pengembangan langkah model EDP yang sesuai. Permasalahan yang menjadi titik awal dalam pembelajaran STEM, dapat dikembangkan melalui proses konkrit melalui kegiatan membuat produk sesuai dengan petunjuk, selanjutnya peserta didik menganalisa permasalahan dari proses dan produk yang telah mereka buat tersebut.

Rumusan masalah dalam kajian ini adalah bagaimanakah variasi dan implementasi pengembangan model pembelajaran STEM di sekolah dasar? Sedangkan tujuannya untuk mendiskripsikan variasi dan implementasi pengembangan model pembelajaran STEM di sekolah dasar.

\section{Pembelajaran Matematika Berbasis STEM}

STEM merupakan sebuah pendekatan yang mengintegrasikan bidang sains, teknologi, rekayasa dan matematika menjadi satu kesatuan yang utuh dalam prosesnya. (Bybee, 2013). Penekanan integrasi pada disiplin sains, teknologi, teknik dan matematika merupakan peluang untuk inovasi dan perubahan dalam ruang kelas matematika (Fitzallen, 2015). Sebagai integrasi dari empat disiplin ilmu, dalam pembelajaran matematika harus ada penyatuan antara sains, teknologi dan teknik. Ketiga disiplin ilmu tersebut harus muncul pada saat bersamaan. (Lasa, et.al, 2020).

Kegiatan pembelajaran STEM dilaksanakan melalui suatu proyek problem based learning, iquiry based learning/discovery based learning dengan menghasilkan suatu produk baik fisik maupun non fisik. Matematika sebagai salah satu bagian dalam integrasi STEM mempunyai peran sebagai disiplin pengetahuan yang menghubungkan antara besaran, ruang, dan angka yang membutuhkan argument logis. (Torlakson, 2014).

Pembelajaran STEM yang dilaksanakan di matematika dapat memfasilitasi peserta didik, tidak hanya menguasai konten keilmuan matematik, tetapi juga keterampilan berpikir matematik. (Sumaryanta \& Agus, 2020). Dalam implementasinya Matematika berperan sebagai house untuk mengintegrasikan Science, Technology, Engineering melalui sebuah proyek untuk menyelesaikan masalah. Kegiatan proyek STEM bercirikan pada Engineering 
Design Process (EDP). EDP merupakan suatu alur siklus yang dilakukan secara berulang yang dapat dilakukan melalui tahapan tertentu. Menurut Capraro et.al (2013) langkah dalam siklus EDP dapat dimulai dari tahap mana saja yang diakhiri dengan sebuah produk dengan hasil yang lebih baik. EDP akan dapat dengan mudah menghubungkan kondisi pembelajaran STEM dengan integrasi kontens STEM itu sendiri (Kelley \& Knowles, 2016). Konsep matematika dalam sains, Teknik dan pendidikan teknologi menunjukkan hubungan yang kuat dalam hal pembelajaran (Berry et.al, 2005).

Berdasar pada teori perkembangan kognitif Piaget, usia peserta didik di SD berada pada tahap operasional konkrit. Bentuk permasalahan-permasalahan yang sifatnya kongkrit, faktual dan dapat diamati secara langsung. Oleh karena itu dalam tahapan EDP STEM perlu dilakukan pengembangan dengan tahapan yaitu meminta mereka untuk mengerjakan terlebih dahulu, selanjutnya difasilitasi untuk penyelesaiannya. Hal ini didasarkan pada desain pembelajaran matematika berbasis STEM perlu adanya penciptaan lingkungan belajar yang sesuai (Burton, 2020). Lingkungan belajar tersebut digunakan sebagai koneksi antara permasalahan nyata dengan konten matematika yang digunakan untuk menyelesaikan masalah tersebut. Dalam teori Vigotsky scaffolding merupakan pemberian masalah yang komplek, sulit dan realisti kepada anak kemudian diberi bantuan secukupnya dalam memecahkan masalah tersebut (Masganti, 2012).

Koneksi antar tahapan dalam EDP saling berkaitan, terutama pada kegiatan awal berupa permasalahan. Koneksi ini penting sebagai upaya menghasilkan produk yang dapat menyelesaikan masalah. Namun demikian berdasarkan beberapa hasil penelitian menunjukkan bahwa kemampuan koneksi matematis peserta didik rendah (Maulida, 2020). Koneksi yang dimaksud merupakan koneksi antar topic matematika, koneksi dengan disiplin ilmu lain (sains) dan koneksi dengan dunia nyata. Sehingga tahapan model EDP STEM perlu dimodifikasi sesuai dengan tahapan perkembangan peserta didik di sekolah dasar. Sebagai ciri pembelajaran berbasis STEM, tahapan ini dapat dikembangkan secara fleksibel sesuai dengan tahap perkembangan dan kemampuan prasyarat yang telah dimiliki peserta didik pada tingkatan tertentu. Banyak variasi model EDP yang dapat dikembangkan di sekolah dasar salah satunya dengan menyederhakan menjadi lima langkah. Pengembangan model Engineering Design Process STEM untuk pembelajaran matematika di sekolah dasar yang dimodifikasi oleh penulis sebagai berikut.

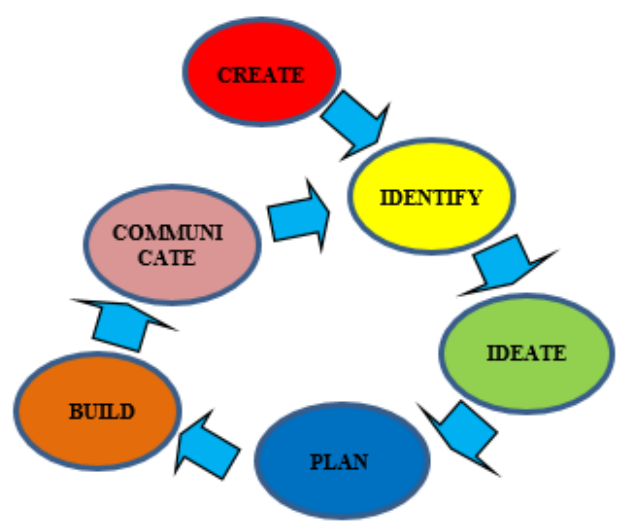

Gambar 1. Pengembangan Model Engineering Design Process di SD 
Desain teknik dapat direpresentasikan dengan menggunakan proses enam langkah, seperti diuraikan di bawah ini.

\section{Langkah 1: Create}

Produk merupakah hasil dari tahap ini. Peserta didik diberikan kegiatan menyelesaikan kegiatan untuk membuat suatu produk atau menyelesaikan kegiatan tertentu. Individu menyelesaikan kegiatan sesuai dengan tahapan yang telah disusun. Selanjutnya dilakukan pengujian untuk memastikan keberfungsian dari produk yang dihasilkan. Pada tahap ditentukan kriteria yang diharapkan dari produk yang dihasilkan agar dilakukan inovasi. Langkah Create bukan produk hasil kemampuan kritis dan kreatif siswa tetapi digunakan sebagai permasalahan agar siswa dapat menganalisa proses dan produk yang telah dibuat berdasarkan petunjuk untuk dikembangkan.

\section{Langkah 2: Identify}

Hasil dari hasil pengujian analisa produk yang telah dibuat, dianalisa dan di definisikan permasalahan dari produk. Dengan mengidentifikasi masalah individu akan mengetahui gambaran permasalahan, sehingga mereka akan mengetahui tujuan pekerjaan desain yang direncanakan sesuasi dengan permasalahan. Setelah permasalah teridentifikasi, selanjutnya dilakukan penelitian berkaitan dengan kemungkinan dari ide untuk menyelesaikan permasalahan pada produk yang telah dibuat. Hasil penelitian ini digunakan untuk mengembangkan ide desain yang akan dirancang pada tahapan selanjutnya.

\section{Langkah 3: Ideate}

Pengembangan ide desain digunakan untuk memodifikasi produk didasarkan pada hasil penelitian di tahap sebelumnya. Ide dari masing-masing individu yang merupakan solusi untuk menjawab permasalahan dari produk yang dihasilkan dapat menghasilkan berbagai macam solusi.

\section{Langkah 4: Plan}

Melalui kegiatan bertukar pikiran dipilih solusi yang terbaik untuk menyelesaikan permasalahan. Ide yang telah dipilih disempurnakan dan dilakukan pengembangan produk sesuai dengan kriteria. Pada kegiatan merekayasa dengan menggunakan matematika, sains dan teknologi yang penting dilakukan. Masing-masing individu dapat mengemukakan ide, evaluasi dan mengkomunikasikan alternatif desain yang dipilih. Ide ini menjadi solusi yang terbaik untuk memodifikasi dan mengembangkan produk yang telah dibuat. Pada kegiatan ini setiap rencana tahapan kegiatan, alat dan bahan yang dibutuhkan dapat digambarkan dan ditulis dengan jelas.

\section{Langkah 5: Build}

Setelah menerapkan Matematika, sains, teknik dan teknologi dalam merencanakan ide, selanjutnya membuat prototipe. Masing-masing individu berkolaborasi menyelesaikan produk sesuai dengan desain yang direncanakan. Produk tersebut bisa saja tidak berupa 
bentuk fisik tetapi juga non fisik. Produk yang telah dibuat selanjutkan dilakukan uji dan evaluasi. Kegiatan pengujian dilakukan secara teliti dengan berbagai macam kemungkinan yang dapat menyempurnakan hasil. Hasil pengujian dicatat dan didokumentasikan sebagai bahan evaluasi untuk meningkatkan produk.

\section{Langkah 6: Communicate}

Pada tahap ini, mengkomunikasikan solusi dari pengembangan produk yang telah dibuat. Pengalaman-pengalaman pada proses pembuatan produk dikomunikasikan dan dianalisis kemungkinan desain untuk diperbaharui dan mendesain ulang untuk menyempurnakan prototipe sesuai dengan kriteria. Dari data dan produk ini, jika memungkinkan dapat dilakukan perbaikan.

\section{Implementasi Pengembangan Model STEM dalam Pembelajaran Matematika Berbasis STEM di SD}

Implementasi pengembangan model pada pembelajaran matematika berbasis STEM di sekolah dasar ini dilaksanakan pada materi pengukuran. Kegiatanya dilaksanakan melalui proyek membuat masker dari bahan kain. Komponen STEM dalam yang terintegrasi meliputi : Sains berupa sifat bahan, Teknologi berupa Teknologi Informasi dan Komunikasi (TIK) untuk mencari referensi tentang sifat bahan dan desain masker. Selain itu teknologi berupa alat yang digunakan dalam menyelesaikan produk. Enjiniring berupa rekayasa bentuk masker sesuai dengan kenyamanan serta bahan yang sesuai dengan fungsinya. Matematika berupa pengukuran. Tahapan model dalam kegiatan ini sebagai berikut:

\section{Langkah 1: Create}

Pada tahap ini peserta didik diberikan lembar kegiatan untuk membuat masker dari bahan kain. Peserta didik diberikan kertas berpetak dengan ukuran masing-masing petak satu sentimeter. Peserta didik diminta membuat desain masker sesuai dengan gambar. Selanjutnya menggunting desain tersebut. Setelah digunting peserta didik menyiapkan bahan kain. Desain dari kertas tersebut kemudian digunakan untuk membentuk pola pada kain sebanyak dua helai. Dari pola kain tersebut disatukan dengan cara dijahit bagian pinggir serta diberikan karet untuk pengikat kain dengan telinga. Produk masker yang telah dibuat tersebut kemudian diujicoba dengan cara dipakai.

\section{Langkah 2: Identify}

Produk masker yang sudah dibuat selanjutnya dianalisa dari bentuk desain, bahan yang digunakan. Masing-masing individu diminta mendefinisikan permasalahan dari produk tersebut. Apakah bentuk desain sudah sesuai dengan bentuk wajah? Apakah bentuk desain sudah memenuhi aspek kenyamanan apabila dipakai? Apakah bahan yang digunakan dapat berfungsi sebagai filtrasi yang baik? Bagaimanakah bentuk desain yang sesuai wajah? Bagaimanakah bentuk desain yang memenuhi aspek kenyamanan? Bahan apakah yang dapat digunakan sebagai filtrasi yang baik? 
Dari identifikasi permasalahan produk yang telah dibuat, selanjutnya peserta didik mengembangkannya menjadi desain yang baru. Desain tersebut meliputi modifikasi bentuk dan bahan yang digunakan. Mereka menggambarkan dalam bentuk sketsa, bagan ataupun tabel. Pada proses ini peserta didik melakukan penelitian tentang bentuk desain, mencari referensi melalui internet tentang bahan terbaik yang dapat digunakan untuk masker.

\section{Langkah 4: Plan}

Dari desain peserta didik dipilih satu desain terbaik untuk dijadikan prototipe. Desain yang dipilih ini didiskusikan melalui kegiatan tukar pikiran untuk menyempurnaan desain. Penyempurnaan desain terpilih didasarkan pada kriteria yang telah ditentukan pada tahap awal. Pada tahap ini termasuk juga penentuan alat dan bahan yang dibutuhkan serta tahapan kegiatan pengerjaannya.

\section{Langkah 5: Build}

Secara berkolaborasi peserta didik menyelesaikan produk masker sesuai dengan desain yang direncanakan. Produk masker yang telah dibuat selanjutkan dilakukan uji dan evaluasi sesuai dengan kriteria.

\section{Langkah 6: Communicate}

Masing-masing kelompok mempresentasikan produk yang telah dibuat. Produk yang telah diselesaikan tersebut sesuai dengan solusi dari pengembangan produk untuk memecahkan permasalahan. Selain itu mereka dapat menceritakan pengalaman selama proses pembuatan termasuk kendala dan cara mengatasinya. Kelompok juga menceritakan alternatif desain yang lain sebagai penyempurnaan produk apabila dibutuhkan.

Penggunaan STEM dalam pembelajaran matematika dikembangkan dikembangkan untuk meningkatkan kualitas proses pembelajaran. Pembelajaran tidak hanya berorientasi pada hafalan dan penyelesaikan soal-soal rutin, melainkan praktik langsung dalam dunia nyata. Pengetahuan matematika yang diperoleh peserta didik digunakan untuk memecahkan solusi dan membuat inovasi. Langkah EDP-STEM yang dikembangkan ini melalui tahapan Create, Identify, Ideate, Plan, Build, Communicate ini akan mempermudah guru dan peserta didik dalam mengimplementasikannya.

Ciri khusus dari langkah dalam model EDP yang dikembangkan ini terletak pada cara guru dalam menghadirkan permasalahan dunia nyata ke dalam pembelajaran matematika berbasis STEM. Masalah dalam bentuk kegiatan membuat produk tertentu kemudian dianalisa. Kegiatan membuat produk pada langkah awal ini mengkonkritkan masalah yang abstrak untuk diidentifikasi peserta didik. Sesuai dengan taraf perkembangan kemampuan berpikir peserta didik di usia sekolah dasar akan sulit apabila masalah yang dihadirkan berupa masalah-masalah abstrak. Selain dapat menganalisa produk yang telah dibuat untuk dimodifikasi dan dikembangkan, peserta didik dapat pula menganalisa keefektifan proses pembuatannya. Pengalaman nyata dalam membuat proyek awal menjadi bahan diskusi yang menarik antar peserta didik. Efisiensi waktu dalam pembelajaran di kelas dapat terjaga. 
Pengembangan ini akan menutupi kelemahan pembelajaran STEM jika dilaksanakan di kelas umum. Seperti diketahui alokasi waktu untuk menyelesaikan satu proyek STEM sangat lama dibandingkan dengan bahan kajian non STEM. Hal ini akan mengganggu ketercapaian kompetensi dasar materi yang ada di kurikulum bagi sekolah yang belum mempunyai kurikulum STEM tersendiri.

\section{Kesimpulan}

Engineering Design Process merupakan siklus pembelajaran STEM yang terintegrasi. Hal ini yang membedakan pembelajaran STEM dan non STEM. Sekolah dasar mempunyai karakteristik berbeda dengan tingkatan yang lain. Dengan karakteristik tersebut maka diperlukan variasi pengembangan model STEM. Variasi yang dapat dikembangkan tersebut meliputi tahapan Create, Ask, Imagine, Plan, Build, Improve. Permasalahan yang diangkat dapat pembelajaran berasal dari produk dari proyek yang telah diselesaikan. Hal ini akan lebih mengkonkritkan masalah ke dalam proses pembelajaran matematika di kelas. Implementasi variasi model ini dilaksanakan dalam proyek membuat masker pada mata pelajaran matematika di kelas 4 sekolah dasar.

\section{Daftar Pustaka}

Anggraini, D., Kartono, \& Veronica, R. B. 2015. Keefektifan pembelajaran CORE berbantuan kartu kerja pada pencapaian kemampuan masalah matematika dan kepercayaan diri siswa kelas VIII. Unnes Journal of Mathematics Education, 4 (3), hlm. 1-9.

Berry, R., Reed, P., Ritz, J., Lin, C., Hsiung, S., \& Frazier, W. 2005. STEM initiatives: Stimulating students to improve science and mathematics achievement. The Technology Teacher, 64(4), 2329.

Burton, 2020. Multiple perspectives of mathematics in STEM among preservice teachers. Journal of Research in Innovative Teaching \& Learning 13. 147-148 Emerald Publishing Limited.

Bybee, R. B. 2013. The case for STEM education: Challenges and Opportunities. Arlington: National Science Teachers Association, NSTA Press.

Capraro et.al. 2013. STEM Project-Based Learning : An Integrated Science, Technology,Engineering, and Mathematics (STEM) Approach (2nd Edition). Rotterdam/Boston/Taipei: Sense Publisher.

English L.D., dan King D. T,. 2015. STEM learning through engineering design: fourth-grade students' investigations in aerospace. International Journal of STEM Education. 2 (14). 1-18.

English, L.D.,. 2016. STEM education K-12: perspectives on integration. English International Journal of STEM Education. 3(3), 1-8.

Fitzallen, Nolaine. 2015. STEM Education: What Does Mathematics Have To Offer? Proceedings of the 38th annual conference of the Mathematics Education Research Group of Australasia, pp. 237-244. Sunshine Coast: MERGA.

Gustiani, I., Widodo, A., \& Suwarma, I. R. 2017. Development and Validation of Science, Technology, Engineering and Mathematics (STEM) Based Instructional Material. In Aip Conference Proceedings (Pp. 1-7).

Joly, Anne. 2016. Six Characteristics of a Great STEM Lesson. [Online]. Diakses dari http://www.edweek.org/tm/articles/2014/06/17/ctq_jolly_stem.html.

Kelley, T. R., \& Knowles, J. G. 2016. A Conceptual Framework for Integrated STEM Education. International Journal of STEM Education, 3(1), 1-11.

Laza, Aitzol, Jaione Abaurrea, Haritz Iribas. 2020. Mathematical Content on STEM Activities. Journal on Mathematics Education, 11, 333-346. 
Maulidaa, Azwida Rosana, Hardi Suyitnob , Tri Sri Noor Asih. 2020. Kemampuan Koneksi Matematis pada Pembelajaran CONINCON (Constructivism, Integratif and Contextual) untuk Mengatasi Kecemasan Siswa. Prosiding Seminar Nasional Matematika. PRISMA 2: 724-731.

Masganti, 2012. Perkembangan Peserta Didik. Medan. Perdana Publishing.

Riyatuljannah, Triwahyu, Suyadi. 2020. Analisis Perkembangan Kognitif Siswa Pada Pemahaman Konsep Matematika Kelas V SDN Maguwoharjo 1 Yogyakarta. EduHumaniora: Jurnal Pendidikan Dasar, 12, 48-54.

Saminanto \& Kartono. 2015. Analysis of Mathematical Connection Ability in Linear Equation With One variable Based on Connectivity Theory. International Journal of Education and Research, 4, 259-270.

Sumaryanta \& Agus, 2020. Rekonstruksi Pembelajaran Matematika di Era Revolusi Industri 4.0, Indonesian Digital Journal of Mathematics and Education, 7. 11-25.

Torlakson. T, 2014. Innovate: A Blueprint for Science, Technology, Engineering, and Mathematics in California Public Education. California: State Superintendent of Public Instruction.

Yusnita, I., Masykur, R., \& Suherman. 2016. Modifikasi model pembelajaran Gerlach dan Ely melalui integrasi nilai-nilai keislaman sebagai upaya meningkatkan kemampuan representasi matematis. Al-Jabar: Jurnal Pendidikan Matematika, 7 (1), 29-38. 